\title{
Objectives, Keys and Results in the Water Networks to Reach the Sustainable Development Goals
}

\author{
Angel Valentin Mercedes Garcia ${ }^{1}$, Petra Amparo López-Jiménez ${ }^{1}$ (D) Francisco-Javier Sánchez-Romero ${ }^{2}$ (D) \\ and Modesto Pérez-Sánchez ${ }^{1, *(1)}$ \\ 1 Hydraulic and Environmental Engineering Department, Universitat Politècnica de València, \\ 46022 Valencia, Spain; anmergar@doctor.upv.es (A.V.M.G.); palopez@upv.es (P.A.L.-J.) \\ 2 Rural and Agrifood Engineering Department, Universitat Politècnica de València, 46022 Valencia, Spain; \\ fcosanro@agf.upv.es \\ * Correspondence: mopesan1@upv.es
}

Citation: Mercedes Garcia, A.V.; López-Jiménez, P.A.; SánchezRomero, F.-J.; Pérez-Sánchez, M. Objectives, Keys and Results in the Water Networks to Reach the Sustainable Development Goals. Water 2021, 13, 1268. https: / / doi.org/10.3390/w13091268

Academic Editor: Peter Davies

Received: 22 March 2021

Accepted: 29 April 2021

Published: 30 April 2021

Publisher's Note: MDPI stays neutral with regard to jurisdictional claims in published maps and institutional affiliations.

Copyright: (c) 2021 by the authors. Licensee MDPI, Basel, Switzerland. This article is an open access article distributed under the terms and conditions of the Creative Commons Attribution (CC BY) license (https:// creativecommons.org/licenses/by/ $4.0 /)$.

\begin{abstract}
The world is continuously searching for ways to improve how water is used for energy. As the population increases, so do the needs for natural resources and, in turn, the needs for energy. This research sought to show how the world has tried to achieve more sustainable forms of pressurized water distribution and to show the results that have been obtained. In this sense, technologies have been used for the production of clean energy, energy recovery instead of dissipation, reprogramming of pumping stations and hybrid systems. In many cases, much lower water and energy requirements are achieved and, in turn, greenhouse gas emissions related to water use are reduced. Sixty-one different water systems were analyzed considering different energy, economic and environmental indicators. The different operation range of these indicators were defined according to sustainable indicators.
\end{abstract}

Keywords: water networks; sustainability; sustainable indicators; energy recovery; GHG emission

\section{Sustainability in the Water Cycle}

The support and reason for change for all life forms is energy. The variability of energy consumption has presented significant changes in recent years due to exponential growth in the human population [1]. A few decades ago, the water-energy nexus focused on producing energy through hydroelectric power plants. Several recent studies created a new perspective on the water-energy binomial. Similarly, these new points of view show water installations as energy consumers [2].

At the same time, climate change as a product of global warming created a challenge for the social and economic development of different nations. One of the most affected resources is water, whose availability has decreased, and the extraction of water is increasingly complex. As a result, there has been a movement in search of alternative sources to obtain water energetically more consumptively [3]. Water is being extracted from underground and desalinized with reverse osmosis, which are processes increasing in popularity. Both methods require large pumping stations to achieve high pressure values and large flows of water, as both pressure and flow determine the power needed by all the equipment [4].

Water and energy have a close relationship due to the existing alterations in the natural hydrological cycle that have occurred to satisfy the world population's needs [3]. The altered water cycle must have sustainability throughout its transport system (economic, ecological, social and physical), which means that it must meet the current and future demands without significant degradation [4].

In the same way, international organizations show in their reports the existence of a great pressure to manage water resources more efficiently. Such pressure increases in proportion to the growth of the human population. Nowadays, it has been determined 
that more than $40 \%$ of humans have deficient water supply [5,6]. Consequently, different international and national programs are being published by governments in order to promote the renewal of old facilities that have a low efficiency as well as to implement facility designs that consider sustainable water policy [7-9] These policies are focused on developing strategies that can adapt to water scarcity and climate variability $[9,10]$. The investment is sometime private, although the majority of cases are supported by public assistance. As an example, the average cost of Spanish irrigation modernization is between EUR 8000 and 10,000/ha, considering all the necessary infrastructure. However, this cost depends on irrigation area as well as the required modernization level [11].

Thanks to the fact that water allows the development of living beings, such as animals as well as vegetables, it is utilized to produce food sources. It is estimated that $70 \%$ of extracted water for consumption in the world is used for agricultural purposes. In fact, it is expected that this water demand will increase up to $42 \%$ by 2050 in different places because of population growth [12].

To increase the efficiency of the water supply, the transportation networks have been developed in a pressurized manner, but this in turn has a higher energy requirement [13]. The energy contributed by the pumping equipment upstream of the network in a water distribution system, which operates in a pressurized way to supply the agrarian demand, is affected depending on the fluctuations in the demand of the crops [14]. These alterations in the operation of pumping equipment could generate moments in which the pipes exhibit excess pressure; therefore, equipment or elements capable of controlling these events must be implemented.

From an energy point of view, hydraulic pumping systems are of greater importance than networks operated by gravity. Knowing the different characteristics of use for irrigation tends to increase the efficiency of energy consumption [15].

Consideration of water scarcity and climate change is key to optimizing water and energy resources in the community and in order to guarantee meeting the demand for water [16]. This challenge should be solved considering the use of information and communications technology (ICT) in the supply and irrigation networks. ICT use is making it possible to improve water use through real-time analysis and planning of the water networks [17] and to increase the feasibility of the water infrastructures [18]. The connection of water, energy and environment is crucial to reaching cleaner production and a circular economy in the water cycle [19]. The integration of renewable energies in the water systems enables enhancement of the weight of sustainability in water infrastructures [20], as well as synergies in the different decisions and policies for water management [21].

Different research studies of water systems related to terms of energy, design and/or sustainability have been published. However, the present research developed an indepth analysis of more than sixty case studies in which the water uses, optimization techniques, environmental and economic indicators were considered. The information from the different case studies was analyzed, obtaining different indicators that allowed them to be compared. The paper shows that design and management must be focused on giving prominence to sustainability in water networks in the coming years.

\subsection{Water Uses}

Water is a natural resource used for the development of life as we know it. That is why the growth of humanity has always been limited by the our ability to obtain water resources [22]. In all populations, this resource plays an essential role in the development of all socio-economic activities, which is why humans have always sought ways to interfere and control the nature of water.

The two main reasons why people seek to interrupt the natural water cycle are: (1) to provide for the demands made by society and (2) to control water energy [23]. The main social demands to which water is subjected are: (i) urban demand, or the endowment of water supplied to meet the sanitary and recreational needs of human beings; (ii) agricultural demand, or providing the volume of water necessary to develop crops and 
animal husbandry that will later serve as food; and (iii) industrial demand, or supplying the amount of water required by industries to efficiently develop each of their processes.

To supply the needs of human beings, the natural hydrological cycle has undergone a number of alterations that add processes to which the water is subjected [13]. Without assuming the natural methods to which the water is exposed (e.g., precipitation, evaporation, runoff, among others), the scheme to which the water is subjected is represented simply by the following illustration (Figure 1).

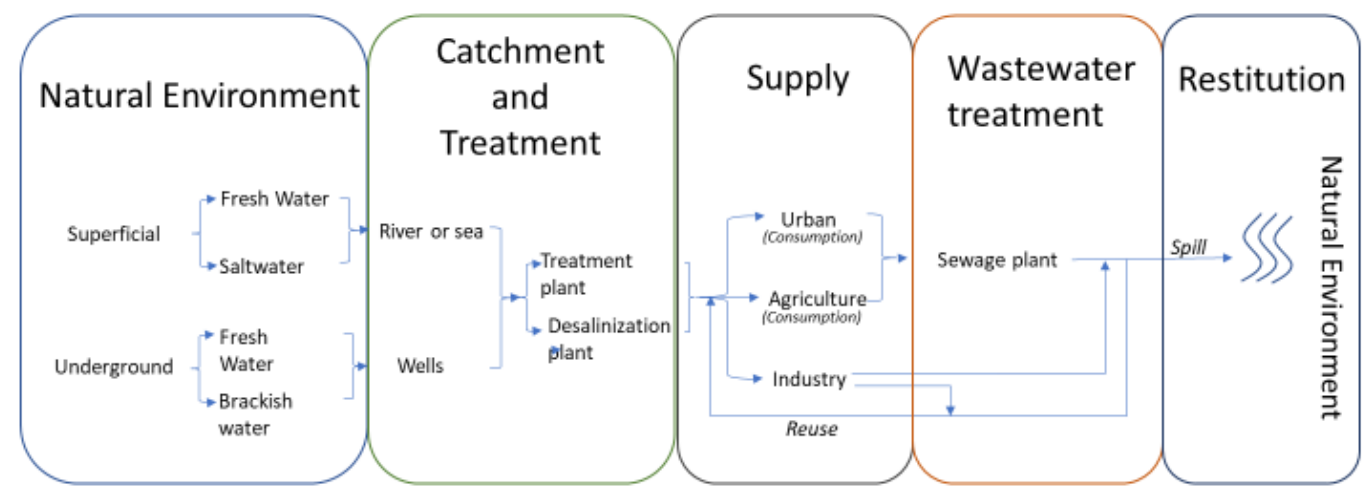

Figure 1. Altered Water Cycle.

The development of technologies has created the capacity to mobilize large amounts of water to distant points that are away from the various sources of water and, as a consequence, has allowed the expansion and increase of the population of human societies. As a result of this population growth, the needs for health services and food sources have increased significantly, resulting in a need for greater volumes of water around the world $[24,25]$.

Figure 2 shows that the extraction of the water resource grows as the population increases. The volume of water lost by evaporation has augmented considerably to $400 \mathrm{~km}^{3}$ /year, which may point to the rise in temperature in response to climate change. In $2020,65 \%$ of all the volume of water withdrawn from the natural environment was used in agriculture, $23 \%$ for urban demand and the other $12 \%$ for other uses [24,25]. Figure 2 shows the positive trend in the water consumption in the different sectors each decade, increasing $600 \%$ from 1920 when the population increased $1000 \%$.

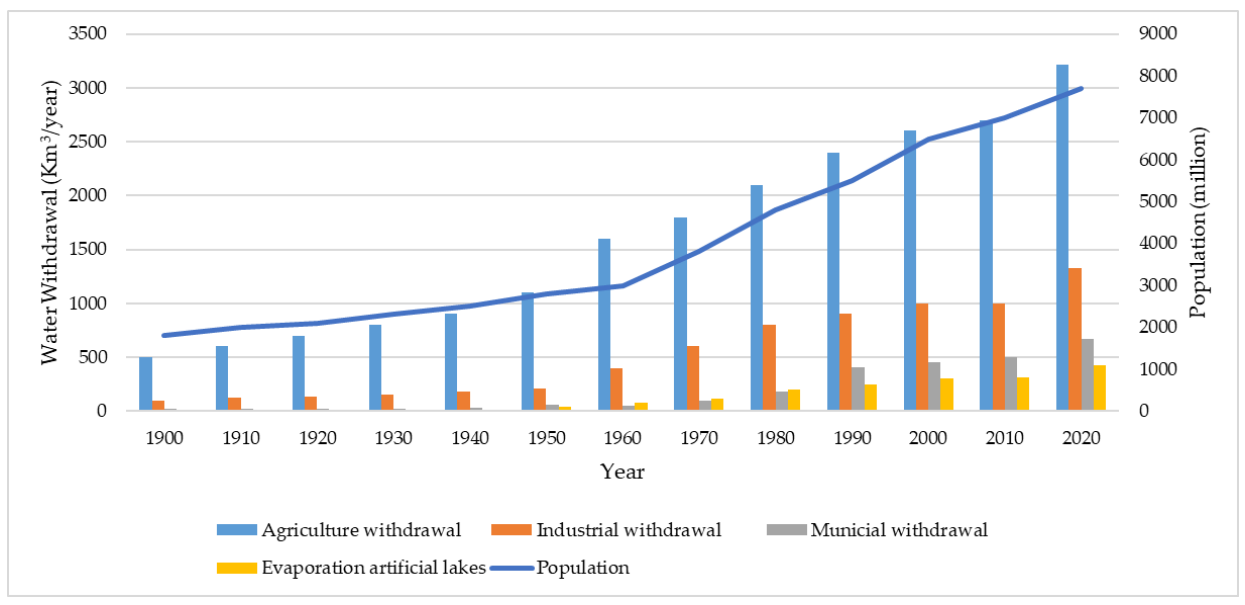

Figure 2. Global population and water withdrawal over time.

\subsection{Consequences of Water Uses in the Environment}

The emission of greenhouse gases resulting from anthropogenic activities generated the degradation of the ozone layer, causing variations in climatic processes and, 
consequently, variations in totally natural methods [22,26,27]. Conventional systems for obtaining energy (e.g., coal, petroleum products, among others) emit greenhouse gases $\left(\mathrm{CO}_{2}\right)$ with a higher proportion while increasing the request to which they are subject. The increased demand for water caused humans to choose hydrological sources with higher energy requirements, such as desalination and even deeper collection wells or tanks with longer distances $[3,28]$. Consequently, the environmental impact of water distribution systems is intensifying.

Although in recent decades hydraulic and environmental engineers have focused their attention on the sustainability of pressurized networks, there are still supply networks in the world whose energy requirement has values that exceed $1000 \mathrm{GWh} /$ year and the emission of $\mathrm{CO}_{2}$ is more than $30 \times 10^{6} \mathrm{t} /$ year $[28,29]$.

Numerous studies on water consumption in the world show that water demand is affected by regional conditions, such as demographics, climate, the ease of obtaining water, among others. The withdrawal of water worldwide is at approximately $3828 \mathrm{~km}^{3} /$ year, where $2662 \mathrm{~km}^{3} /$ year is assigned to agricultural use, being equivalent to $70 \%$ of the total volume, $784 \mathrm{~km}^{3}$ /year for the industrial demand, this being $20 \%$ of the total volume, and the remaining $10 \%$ equivalent to $382 \mathrm{~km}^{3}$ /year supplies domestic requirements [30,31].

Due to the current environmental crisis, it is necessary to reduce the emission of greenhouse gases by recovering energy with sustainable water distribution systems [32]. The elements commonly used to release energy from pressurized systems are valves. These elements can modify the loss of energy in water passage by increasing the friction that hinders the movement of water, thus releasing that energy in the form of heat. Based on the foregoing, the present research was carried out to identify elements that can take advantage of the energy required to be removed from hydraulic systems: pumps as turbines installed to substitute valves.

The installation of pumps used as turbines (PATs) at small hydroelectric plants can lead to an improvement in the efficiency of the networks. In the same way, they offer an economic and environmental benefit to the administrative body of the drinking water distribution networks [33]. This technology has been developed more and more thanks to the existence of pumps that have been removed from systems yet still have the capacity to be used to carry out other tasks, such as energy recovery.

The objective of this article is to show the relationship between the water, sustainability and feasibility in the water distribution systems. It demonstrates that water consumption carries with it an energy requirement, an emission of greenhouse gases and, in turn, an important economic expense as a result of the processes required to provide this resource in quantity and quality for consumers. The research conducted an analysis that compared variables that considered the number of consumers and a group of proposed indicators that relate to water consumption, energy requirements, greenhouse gas emissions and required economic investment per capita. The goal was to use this group of indicators to enable water managers to classify their water systems according to sustainable criteria that measure the degree to which different targets are reached and which are included in the sustainable development goals (SDGs).

\section{Materials and Methods}

The analysis of water systems was studied across the different scenarios, although energy improvement was mainly analyzed in 40 of the 61 examples from the published research. The development of optimization procedures was key to developing more efficient systems. However, the sustainability improvement of the water systems should be linked to the development of optimization procedures to increase attention to the global indicators in which the social, economic and environmental targets each acquire significance in the water management of the systems. This issue of perspective can be observed when addressing the analysis of the different published water systems. 


\subsection{Published Case Studies}

Improving sustainability in water systems must be correlated when different techniques are applied to improve the energy ratio in water systems. To do so, the present research analyzed 61 different case studies that were published in the literature. Table 1 shows the different analyzed case studies, which were located in different countries of the world.

Energy consumption and expenditure were recorded before and after making changes in the morphology of a drinking water distribution network [15,33,34]. Similar to these case studies, there are others that show the variation in greenhouse gas emissions, showing a decrease in values of more than $12 \%$. These modifications demonstrate the commitment to reducing the environmental impact of processes related to water distribution.

To compare the behavior of the different systems, in the case studies in which the data were not obtained directly from other articles, energy consumption values per injected cubic meter were assumed, by which the networks were categorized according to their utility and the average flow injected into the network.

In continuation of the aforementioned, in networks designed for agricultural use: small networks had an average flow lower than $1200 \mathrm{~L} / \mathrm{s}$, the medium network flows were between $120 \mathrm{~L} / \mathrm{s}$ and $6000 \mathrm{~L} / \mathrm{s}$, and extensive networks had flows higher than $6000 \mathrm{~L} / \mathrm{s}$. In the networks used to supply domestic demand, networks with average flows lower than $25,000 \mathrm{~L} / \mathrm{s}$ were categorized as small, medium networks with average flows between 25,000 L/s and 100,000 L/s. Finally, large networks had flows that exceeded 100,000 L/s. The energy consumption assigned for each of the various networks were small agricultural $3 \mathrm{kWh} / \mathrm{m}^{3}$, medium agricultural $2 \mathrm{kWh} / \mathrm{m}^{3}$, large agricultural $1.5 \mathrm{kWh} / \mathrm{m}^{3}$, small domestic $4 \mathrm{kWh} / \mathrm{m}^{3}$, medium domestic $3 \mathrm{kWh} / \mathrm{m}^{3}$ and large domestic $2 \mathrm{kWh} / \mathrm{m}^{3}$.

Table 1. Information of the studies cases.

\begin{tabular}{|c|c|c|c|c|c|c|c|c|c|c|c|}
\hline & Year & Country & Ref. & ID & Year & Country & Ref. & ID & Year & Country & Ref. \\
\hline 1 & 2020 & Spain & [35] & 22 & 2015 & Italy & [36] & 42 & 2011 & Uzbekistan & [37] \\
\hline 2 & 2017 & Spain & [15] & 23 & 2015 & Italy & [36] & 43 & 2019 & UK & [38] \\
\hline 3 & 2019 & Portugal & [39] & 24 & 2015 & Italy & [36] & 44 & 2019 & UK & [38] \\
\hline 4 & 2019 & Spain & [40] & 25 & 2008 & Italy & [41] & 45 & 2019 & UK & [38] \\
\hline 5 & 2016 & Spain & [42] & 26 & 2010 & Spain & [43] & 46 & 2018 & Spain & [44] \\
\hline 6 & 2018 & Portugal & [45] & 27 & 2010 & Spain & [43] & 47 & 2012 & Italy & [46] \\
\hline 7 & 2017 & Spain & [34] & 28 & 2013 & Ireland & [47] & 48 & 2016 & Switzerland & [48] \\
\hline 8 & 2014 & UK & [49] & 29 & 2013 & Ireland & [47] & 49 & 2012 & India & [50] \\
\hline 9 & 2014 & Austria & [51] & 30 & 2013 & Ireland & [47] & 50 & 2016 & Switzerland & [52] \\
\hline 10 & 2014 & Italy & [53] & 31 & 2014 & Italy & [54] & 51 & 2001 & Greece & [55] \\
\hline 11 & 2014 & China & [56] & 32 & 2010 & Portugal & [57] & 52 & 2001 & Greece & [55] \\
\hline 12 & 2011 & Portugal & [58] & 32 & 2010 & Portugal & [57] & 53 & 2001 & Greece & [55] \\
\hline 13 & 2012 & Iran & [59] & 33 & 2017 & Spain & [60] & 54 & 2007 & Spain & [61] \\
\hline 14 & 2015 & Colombia & [62] & 34 & 2014 & Spain & [63] & 55 & 2014 & Norway & [64] \\
\hline 15 & 2013 & Spain & [65] & 35 & 2013 & Spain & [66] & 56 & 2014 & France & [64] \\
\hline 16 & 2012 & Greece & [67] & 36 & 2019 & Spain & [68] & 57 & 2014 & Canada & [64] \\
\hline 17 & 2012 & Greece & [67] & 37 & 2019 & Spain & [68] & 58 & 2014 & Italy & [64] \\
\hline 18 & 2015 & Italy & [69] & 38 & 2019 & Peru & [68] & 59 & 2012 & Jordan & [70] \\
\hline 19 & 2000 & Australia & [71] & 39 & 2013 & Spain & [72] & 60 & 2008 & Portugal & [73] \\
\hline 20 & 2020 & Spain & [74] & 40 & 2017 & Greece & [75] & 61 & 2015 & Italy & [76] \\
\hline 21 & 2014 & UK & [49] & 41 & 2006 & Australia & [77] & & & & \\
\hline
\end{tabular}

\subsection{Optimization to Improve the Sustainability}

There are studies carried out on the optimization of pressurized water distribution networks that show that by making modifications to the elements that compose it, the efficiency of the network can be increased, more energy can be recovered, and the cost associated with the distribution of water can be reduced. In economic terms, to optimize a network, it is possible to reduce the project cost or reduce the payback time of the infrastructure investment [35,36].

To carry out an optimization proposal, water managers should have the general characteristics of the network (e.g., topology, diameters, required flows, working pressures, the elevation of the different points of the network, regulation equipment, among others) [78]. 
The variations in the programming in the pumping stations, the integration of frequency inverters and the installation of elements for energy recovery are practices that are increasingly important. The networks taken as case studies on sustainability optimization are described below, showing the results obtained in each one [79].

Increasingly, humanity focuses on ensuring that the resources it uses for the development of socioeconomic activities have greater environmental sustainability, so many authors focus their attention on the development of procedures and technologies that produce the energy they need and that allow systems to be self-sufficient in some way. In water distribution systems, optimization techniques focus on transforming the typology of the different networks, modifying the pumping systems, recovering energy instead of dissipating it or using a renewable energy source. Another great focus that pressurized distribution systems have is their economical design, which is a factor that significantly influences the decisions that humans make. That said, many studies are based on the optimization and/or reduction of costs related to the collection, distribution and treatment of water.

Each of the methods has a variable or a group of variables that are taken as an orientation for the characteristics that each person is looking for. Table 2 shows a collection of data from studies in which different optimization methods were implemented, accompanied by the method's objective function, variables taken as tools to modify the network and finally whether it emphasizes its optimization in terms of sustainability. Additionally, Table 2 indicates whether improvements in global sustainability (i.e., environmental, economic, social) were considered along with other indicators used as part of the optimization procedure, sustainability being different from general energy indicators.

Table 2. Optimization of applied techniques in water systems.

\begin{tabular}{|c|c|c|c|c|c|}
\hline Optimization Type & Objective Funtion & Variables & $\begin{array}{l}\text { Are Recovery Systems } \\
\text { Installed? }\end{array}$ & $\begin{array}{l}\text { Is the Concept of Global } \\
\text { Sustainability Considered? }\end{array}$ & Reference \\
\hline $\begin{array}{l}\text { Decrease in consumed } \\
\text { energy. }\end{array}$ & $\begin{array}{l}\text { Reduction of energy } \\
\text { supplied for water } \\
\text { supply. }\end{array}$ & $\begin{array}{l}\text { Flow } \\
\text { Pressure }\end{array}$ & No & No & {$[49,54,68]$} \\
\hline Energy recovery. & $\begin{array}{l}\text { Decrease in the energy } \\
\text { dissipated by the } \\
\text { different elements in the } \\
\text { network. }\end{array}$ & $\begin{array}{c}\text { Flow } \\
\text { Pressure } \\
\text { Dissipated energy } \\
\text { Recovered energy }\end{array}$ & Yes & No & {$[15,35,45,53]$} \\
\hline $\begin{array}{c}\text { Self-sufficient } \\
\text { distribution network. }\end{array}$ & $\begin{array}{l}\text { Use a renewable energy } \\
\text { source capable of } \\
\text { sustaining the energy } \\
\text { requirements related to } \\
\text { water. }\end{array}$ & $\begin{array}{l}\text { Required energy, } \\
\text { recovered energy, } \\
\text { generated energy. }\end{array}$ & Yes & Yes & {$[48,57,60,64]$} \\
\hline $\begin{array}{l}\text { Reduction of costs } \\
\text { related to the use of } \\
\text { water. }\end{array}$ & $\begin{array}{l}\text { Decrease in the } \\
\text { operating cost of all } \\
\text { processes that have to } \\
\text { do with water. }\end{array}$ & $\begin{array}{c}\text { Pressure } \\
\text { Flow } \\
\text { Produced energy } \\
\text { Energy cost }\end{array}$ & Yes & No & {$[49,58,62]$} \\
\hline $\begin{array}{l}\text { Control pressure of } \\
\text { different points in a } \\
\text { network. }\end{array}$ & $\begin{array}{l}\text { Reduce the pressure } \\
\text { and consequently } \\
\text { control the flow injected } \\
\text { into a network to reduce } \\
\text { water losses. }\end{array}$ & $\begin{array}{c}\text { Pressure } \\
\text { Flow } \\
\text { Pipe characteristics } \\
\text { Hydraulics accessories }\end{array}$ & No & No & {$[36,49,51,56]$} \\
\hline $\begin{array}{l}\text { Control of water } \\
\text { consumption. }\end{array}$ & $\begin{array}{l}\text { Create strategies that } \\
\text { reduce the water } \\
\text { requirements and/or } \\
\text { the flow injected into } \\
\text { the network. }\end{array}$ & $\begin{array}{c}\text { Energy used } \\
\text { Dissipated energy } \\
\text { Flow } \\
\text { Pressure }\end{array}$ & No & No & {$[43,59,71]$} \\
\hline $\begin{array}{l}\text { Improved sustainability } \\
\text { in pressurized } \\
\text { networks. }\end{array}$ & $\begin{array}{l}\text { Take measures in } \\
\text { different networks to } \\
\text { improve the } \\
\text { sustainability of } \\
\text { pressurized distribution } \\
\text { systems. }\end{array}$ & $\begin{array}{c}\text { Energy used related to } \\
\text { water } \\
\text { GHG emission }\end{array}$ & No & Yes & {$[34,39,42,57]$} \\
\hline $\begin{array}{l}\text { Increased energy } \\
\text { efficiency supplied to } \\
\text { water distribution } \\
\text { systems. }\end{array}$ & $\begin{array}{l}\text { Create ways to use } \\
\text { more efficiently and } \\
\text { sustainably the energy } \\
\text { supplied to water } \\
\text { services. }\end{array}$ & $\begin{array}{c}\text { Energy required in a } \\
\text { network } \\
\text { Energy supplied in a } \\
\text { network } \\
\text { Recovered energy } \\
\text { Dissipated energy }\end{array}$ & Yes & No & {$[34,57,70]$} \\
\hline
\end{tabular}




\subsection{Indicators to Measure the Sustainability in Water Systems}

In order to determine the performance of the water distribution networks, it must be possible to record and process data that serve to qualify all the stages of the service in function - that is why the indicators were taken from service as tools that work to quantify the functionality of the systems. Possible continuous improvement of water and sanitation services is accomplished through rigorous, universal and systematic evaluation [80]. Indicators force people to think about where development is taking them [81]. For the indicators to be able to cover the essential points, different authors divided their structure into different groups that included: (1) quality of service, (2) efficiency in planning and execution of investments, (3) operational efficiency, (4) efficiency in business management, (5) financial sustainability, (6) access to service and (7) environmental sustainability [37-39]. Different indicators are defined in Table 3. The analysis of the water networks, including these indicators enable water managers to assess the sustainable improvement in their systems. Additionally, the inclusion of these indicators enabled measurement of the compliance with the different targets in sustainable development goals.

Table 3. Indicators vs. measured SDGs.

\begin{tabular}{|c|c|c|c|c|}
\hline Indicator & Identification & Reference & SDG & Target \\
\hline Environmental & Annual supplied energy & [82] & $\begin{array}{c}\text { SDG-7 } \\
\text { Clean Energy }\end{array}$ & $\begin{array}{l}\text { Increase substantially the share of } \\
\text { renewable energy in the global } \\
\text { energy mix }\end{array}$ \\
\hline Environmental & Recovered Energy & {$[83,84]$} & $\begin{array}{c}\text { SDG-7 } \\
\text { Clean Energy }\end{array}$ & $\begin{array}{l}\text { Increase substantially the share of } \\
\text { renewable energy in the global } \\
\text { energy mix }\end{array}$ \\
\hline Environmental & GHG & [81] & SDG-7 and SDG 12 & $\begin{array}{l}\text { Reduce the amount of greenhouse } \\
\text { gas emissions to take action in the } \\
\text { fight against global warming }\end{array}$ \\
\hline Social & Risk infection & [81] & $\begin{array}{c}\text { SDG-6 } \\
\text { Water and sanitation }\end{array}$ & $\begin{array}{l}\text { Implement integrated water } \\
\text { resources management at all levels, } \\
\text { including through transboundary } \\
\text { cooperation as appropriate }\end{array}$ \\
\hline Economic & Total unit cost & [82] & $\begin{array}{l}\text { SDG-11 } \\
\text { Sustainable cities and } \\
\text { communities }\end{array}$ & $\begin{array}{c}\text { Enhance inclusive and sustainable } \\
\text { urbanization and capacity for } \\
\text { participatory, integrated and } \\
\text { sustainable human settlement } \\
\text { planning and management }\end{array}$ \\
\hline
\end{tabular}

\section{Results}

\subsection{Worldwide Global Values}

In different countries, the volume of water extraction from the natural environment has different values. Figure 3A shows the volume of water required annually by the various continents, with the Asian continent being the largest consumer, having an average annual volume withdrawn of $2378 \mathrm{~km}^{3}$ /year, this value being $62 \%$ of the total volume withdrawn. This is followed by North America with $525 \mathrm{~km}^{3}$ /year equivalent to 14\%, Europe with $418 \mathrm{~km}^{3}$ /year, Latin America $251 \mathrm{~km}^{3}$ /year, Africa with $217 \mathrm{~km}^{3} /$ year, Oceania with $26 \mathrm{~km}^{3}$ /year and finally the countries of the Caribbean with the value of $13 \mathrm{~km}^{3}$ /year, equivalent to only $0.3 \%$ of the total volume extracted $[12,30,31]$.

The use of water involves significant energy expenditure, which is why the waterenergy relationship has been a focus of attention in the scientific community. To determine the energy consumption linked to water, it is necessary to know the characteristics of the fluid, be it its concentration of metals, the ease or difficulty of obtaining it, its salinity, $\mathrm{pH}$, among others. There are studies that have sought to tabulate the energy requirement of all activities involving the use of water (e.g., treatment and pump stations). These studies served as a reference to create an approximation of the energy footprint that the different pressurized water distribution systems could have. An approximation of energy 
expenditure of 11,474,000 GWh/year can be assigned worldwide following the studies of [85-89].

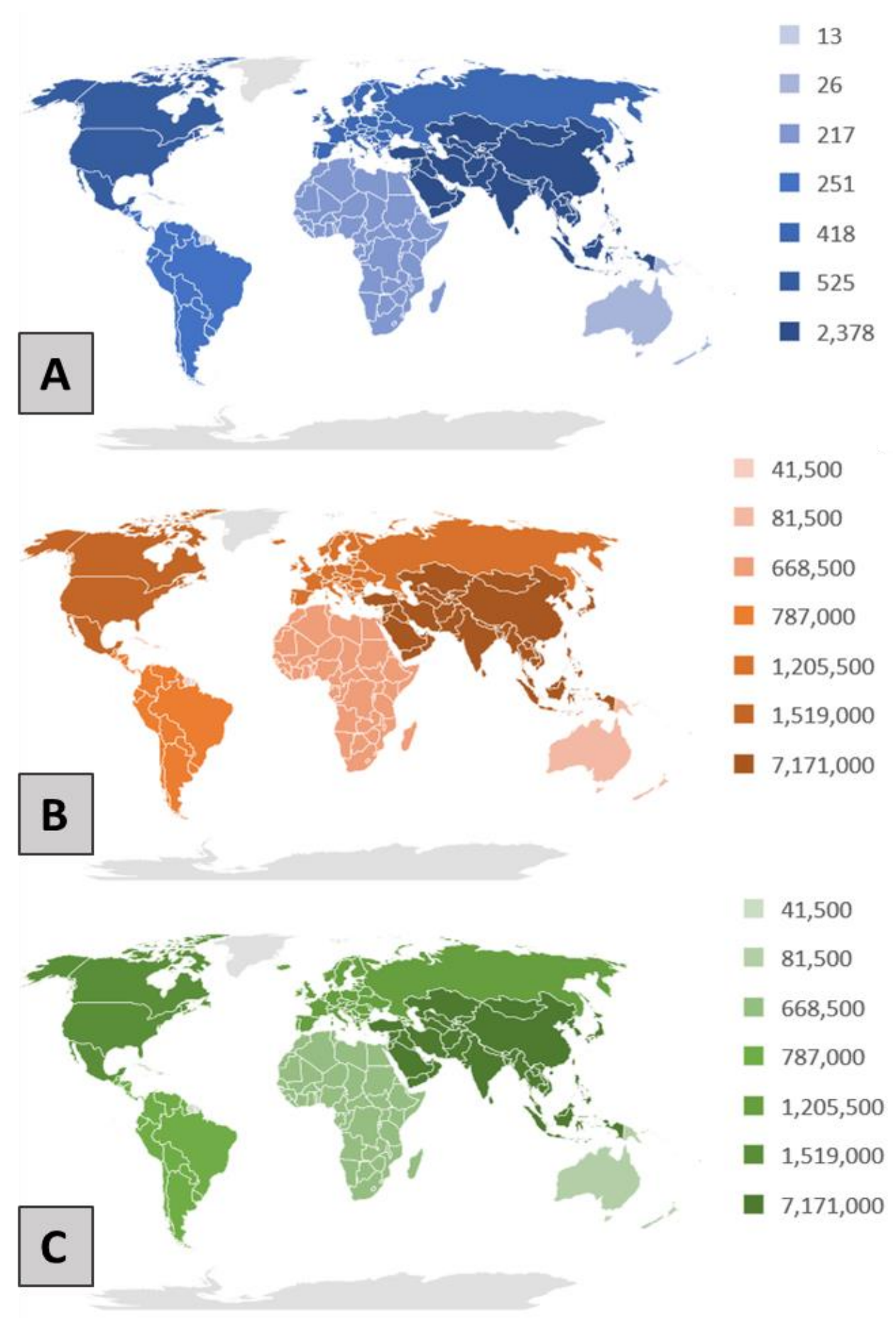

Figure 3. Analysis indicators related to water usage. (A) Total water withdrawals $\left(\mathrm{km}^{3} /\right.$ year), (B) energy requirements ( $\mathrm{kW} /$ year) and (C) GHG emissions ( $\mathrm{tCO}_{2} \mathrm{e} /$ year).

Figure $3 \mathrm{~B}$ shows the energy expenditure assigned in various locations in the world because of water activity. Asia is the continent with the highest energy requirement. Its value is $7717 \times 10^{3} \mathrm{GWh} /$ year, being $62 \%$ of the world energy requirement. It is followed by North America with a value of $1519 \times 10^{3} \mathrm{GWh}$ /year. Europe is in third place; its value is 1,205,500 GWh/year. After them, Latin America consumes $787 \times 10^{3} \mathrm{GWh} /$ year, Africa 
with $668 \times 10^{3} \mathrm{GWh} /$ year, Oceania with $81.5 \times 10^{3} \mathrm{GWh} /$ year and finally the Caribbean with $41 \times 10^{3} \mathrm{GWh}$ /year, equivalent to $0.4 \%$ of the total requirement.

The emission of greenhouse gases was placed in the focus of the scientists' study because emissions have a close relationship with the energy requirements of water distribution systems. The use of commonly functional machinery based on fossil fuels associate energy expenditure with a GHG emission value. It is important to consider new irrigation facilities, since the management of change from traditional irrigation (free open channels) to water pressurized systems causes too many advantages relative to hydraulic efficiency and reduction of water volume use, but pressurized systems increase the average demanded power by $2 \mathrm{~kW} / \mathrm{ha}$, and therefore increase the GHG emissions if non-renewable energies are used [61].

Figure 3C shows a calculated GHG emission value using the Mushtag method [61]. This procedure serves as a reference for determining the different amounts of GHG emission. Grouping the values by continent, it can be determined that Asia emits $62 \%$ of the GHG related to the use of water, having a value of $7.25 \times 10^{9} \mathrm{t} \mathrm{CO}_{2}$ e/year, followed in turn by North America with an emission of $1.54 \times 10^{9} \mathrm{t} \mathrm{CO}_{2}$ e/year, Europe with $1.22 \times 10^{9} \mathrm{t} \mathrm{CO}_{2} \mathrm{e} /$ year, Latin America with $0.8 \times 10^{9} \mathrm{t} \mathrm{CO}_{2} \mathrm{e} /$ year, Africa with $0.68 \times 10^{9} \mathrm{tCO}_{2}$ e/year, Oceania with $0.09 \times 10^{9} \mathrm{tCO}_{2} \mathrm{e} /$ year and the Caribbean with the lowest emission value with $0.042 \times 10^{9} \mathrm{t} \mathrm{CO}_{2}$ e/year.

The different numbers of inhabitants on each continent must be considered: in Asia, there are 4.623 million inhabitants; in North America 369 million; the Caribbean has 44 million; Latin America has 620 million; Africa 1352 million; Oceania 42 million and Europe 743 million [64]. These differences raise the uncertainty of the relationship of the aforementioned factors (volume, energy and GHG) depending on the inhabitants of each continent, which is why a per capita analysis of them is shown and carried out.

Figure $4 \mathrm{~A}$ shows the volume of water consumed per capita with respect to the different continents, leaving the North American continent as the largest consumer with consumption of $1423 \mathrm{~m}^{3}$ /year, followed by Oceania with a consumption of $619 \mathrm{~m}^{3} /$ year, then Europe with $563 \mathrm{~m}^{3}$ /year, Asia with $514 \mathrm{~m}^{3}$ /year, Latin America with $405 \mathrm{~m}^{3}$ /year and finally the African continent with an annual per capita water consumption of $161 \mathrm{~m}^{3} /$ year.

Figure $4 \mathrm{~B}$ shows the distribution of energy consumption related to water use according to the population of each continent, with North America as the largest consumer per capita with consumption of $4116.5 \mathrm{kWh}$ /year, followed by Oceania with $1940.5 \mathrm{kWh}$ /year. Europe and Asia have a consumption of $1622.5 \mathrm{kWh} /$ year and $1551.1 \mathrm{kWh} /$ year, respectively. Latin America takes $1269.4 \mathrm{kWh}$ /year, Caribbean consumes $943 \mathrm{kWh} /$ year and finally Africa shows a consumption around $484.5 \mathrm{kWh} /$ year.

Figure 4C shows the GHG emission per capita in each continent, leaving the North American continent as the leader in emissions with a value of $4.16 \mathrm{tCO}_{2} \mathrm{e} /$ year. It is followed by Oceania, whose value is $1.96 \mathrm{tCO}_{2} \mathrm{e} /$ year. Europe is located in third place, showing values around $1.64 \mathrm{t} \mathrm{CO}_{2} \mathrm{e}$ /year; Asia with $1.57 \mathrm{t} \mathrm{CO}_{2} \mathrm{e}$ /year; Latin America with $1.28 \mathrm{t} \mathrm{CO}_{2} \mathrm{e}$ /year; the Caribbean with $0.95 \mathrm{t} \mathrm{CO}_{2} \mathrm{e} /$ year and lastly as the least producer of GHG related to water use per capita is the African continent with a value of $0.50 \mathrm{tCO}_{2} \mathrm{e} /$ year.

\subsection{Renewable Systems to Improve the SDGs}

Figure 5 shows how the average flow used in the different networks varies before and after the modification. In the initial state of the systems, there are behaviors that reach values that exceed $500 \mathrm{~L} / \mathrm{s}$ and a maximum value obtained of $1250 \mathrm{~L} / \mathrm{s}$, while when making any of the aforementioned modifications, all the average flow values in the different networks are maintained below $490 \mathrm{~L} / \mathrm{s}$. This assumes that by installing a device to optimize the system, water consumption is reduced. Comparing the frequency of the MS to OS shows that the values of flow tend to be more concentrated in lower levels of consumption than what is appreciable in the OS values. It indicates that most of the time the water networks operate with lower values of their total capacity. Usually, it is because the water systems are sized under hypotheses of the users' demand. This accumulated 
high frequency of low flows allows water networks to reduce the energy footprint of water distribution systems.

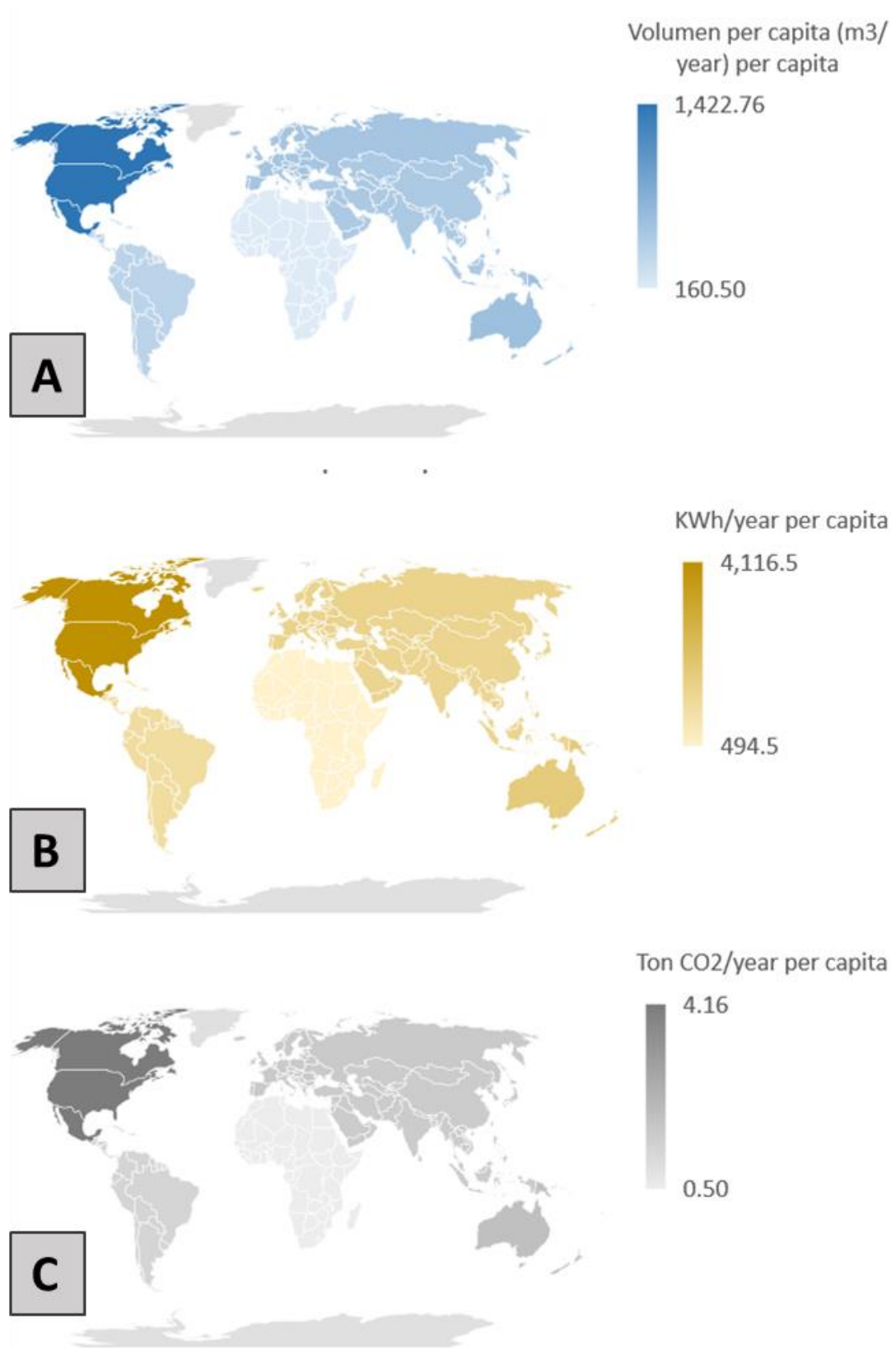

Figure 4. Analysis per capita of indicators related to water usage. (A) Total water withdrawals $\left(\mathrm{km}^{3}\right.$ /year), (B) energy requirements ( $\mathrm{kW} /$ year) and (C) GHG emission $\left(\mathrm{t} \mathrm{CO}_{2} \mathrm{e} /\right.$ year).

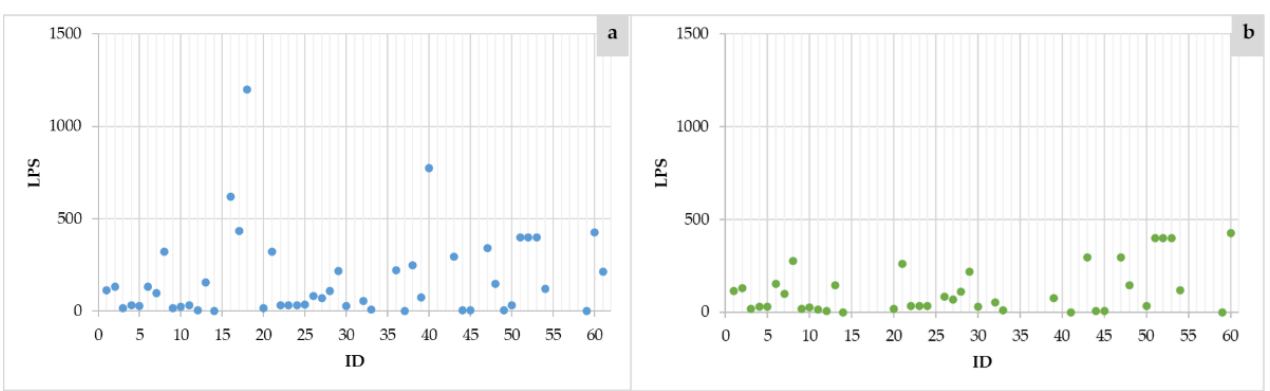

Figure 5. Average Flow (L/s) for OS (a) and MS (b). 
The consumption of water-related to the use of water (Figure 6) reaches values that exceed $5 \times 10^{5} \mathrm{MWh} /$ year, and in the same way, there is a peak consumption value of $20 \times 10^{5} \mathrm{MWh} /$ year. Unlike the initial behavior, when modifying the pressurized water supply network's morphology, the energy consumption values remain below $1.5 \times 10^{5} \mathrm{MWh} /$ year except for the peak consumption value, which is punctual, showing $4 \times 10^{5} \mathrm{MWh} /$ year. By comparing the peak values, it can be determined that a reduction in energy consumption of up to $80 \%$ of the existing value in an analyzed network could be achieved by making any alteration in the network. The recurrence of high values tends to be lower in the analysis, as can be seen. The introduction of the renewable systems caused the reduction of the consumed energy in the water systems using non-renewable resources, which caused a direct decrease in the emissions as well as a decrease in exploitation costs. However, the consumed energy can also be reduced by changing the management of the water systems. An example of this reduction was published by [15] in which the management optimization reduced the energy, cost and energy footprint in $12.26 \%, 15.54 \%$ and $15.04 \%$, respectively, considering that there was an increase in the distributed volume of $9.07 \%$.
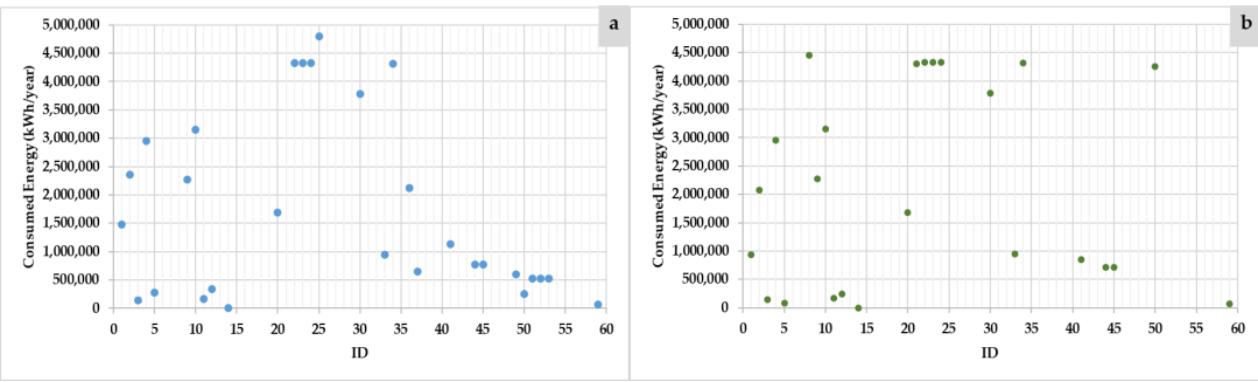

Figure 6. Energy consumed related to water usage for OS (a) and MS (b).

Depending on the reduction in energy consumption and the average flow of water through a network, the emission of greenhouse gases related to the use of water is also modified. This is shown in Figure 7, in which there are different supplies in its original operating station that emit more than 500,000 $\mathrm{t} \mathrm{CO}_{2}$ /year and an analyzed peak value of 2,000,000 $\mathrm{t} \mathrm{CO}_{2}$ /year. In contrast, by modifying these networks, the GHG emission values remain below 300,000 $\mathrm{tCO}_{2}$ /year /year, assuming a theoretical average reduction of greenhouse gases emission between 582 and $877 \mathrm{~g} \mathrm{CO}_{2} / \mathrm{kWh}$ [90].
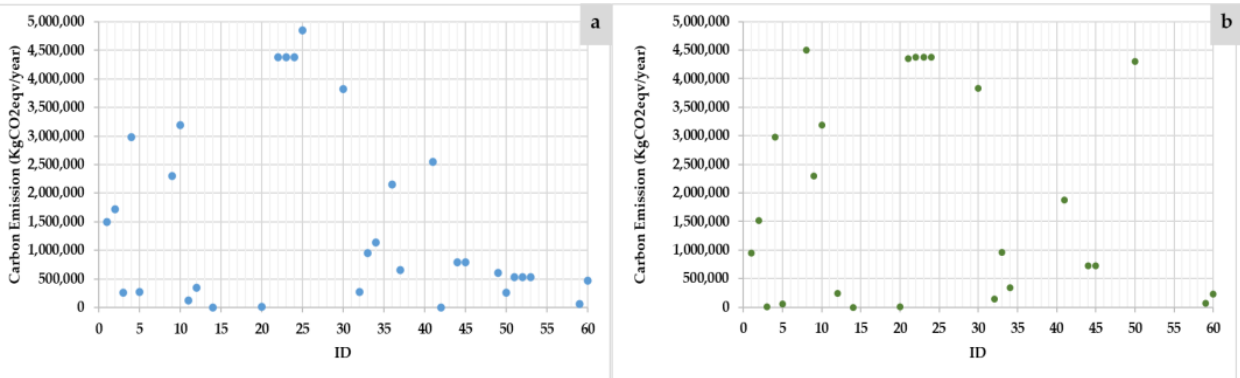

Figure 7. GHG emission related to water usage for OS (a) and MS (b).

However, the development of water pressurized systems supported with the introduction of renewable systems, which reduced the dependency of energy consumption of the other non-renewable resources (i.e., coal or gas), improves other environmental indicators. Renewable systems have a high social impact on the population, and they promote advantages, which are independent of the payback of the facilities. In developing countries, the use of these systems opens the possibility of supplying consumers with both water and energy, increasing their quality life. In these countries, the development of 
water pressurized systems is linked to use of renewable facilities (i.e., photovoltaic, pumps working as turbines, wind turbines, among others). Both vital resources (i.e., energy and water) contribute to increase the success, and therefore the feasibility of these facilities cannot be measured in the GHG reductions and payback - they should show the subjective impact in the populations relative to social aspects, which are linked to some SDGs, such as SDG-1 No poverty, SDG-2 Zero Hunger, SDG-6 Clean Water and Sanitation, SDG-7 Affordable and Clean Energy and SDG-13 Climate Action. Developing water pressurized systems in these areas often need implementation assistance from international and national programs [91,92].

One of the main indicators used for decision-making is the monetary factor, which, as shown in Figure 8, when making changes in the operation and element that has a pressurized supply network, the annual energy cost related to water use is maintained at values below 1,500,000 $€$ /year except for a peak value that reaches a cost of almost $40 \mathrm{M} € /$ year. If the initial operating systems are maintained, the costs exceed $70 \mathrm{M} € /$ year, and there is a peak value of almost $300 \mathrm{M} €$ /year. Particularly, [15] reductions in operational costs decreased from EUR 0.035 to $0.029 / \mathrm{m}^{3}$, an improvement of $15.54 \%$. However, the energy cost is linked to energy prices as well as the consumption schedule, which has a great significance when the water pressurized systems is pumped and the network is used to irrigate. In this case, it is crucial to take advantage of the off-peak hours. In pumped supply networks, the operation time is of less significance because the users demand is continuous, and the water manager cannot schedule the pumped operation range. Along this line, many water managers are installing renewable systems to generate green energy and disengage their connection to the grid. For these infrastructures, which combine consumption on-grid and off-grid, the best solution is the proposal of an energy management strategy for pumped hydro storage systems to manage surplus renewable energy when hybrid systems are installed [93].
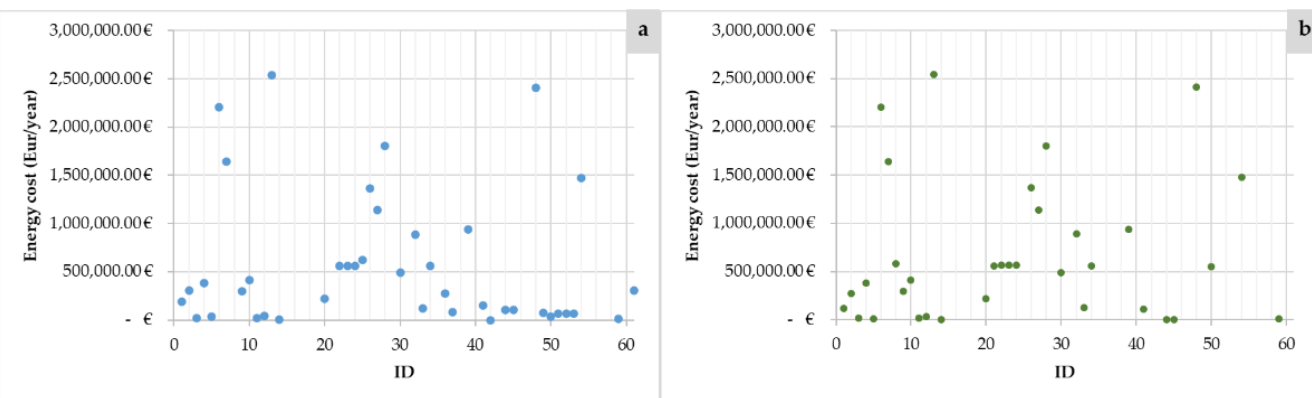

Figure 8. Energy cost related to water usage for OS (a) and MS (b).

The sustainability of water distribution networks is proposed here as a verification of per capita consumption for domestic consumption networks and per hectare for agricultural consumption. That is why the following analysis studies the efficiency and sustainability of the different systems based on the number of units they supply, a value that is used to compare networks of different sizes in the same analysis group. When the energy consumption of the different case studies is measured by units (per capita or hectare), different values are observed. In the initial state, it can be observed that energy consumption has values that reach $50,000 \mathrm{kWh} /$ year per unit of use and that in one of the cases the consumption reached 250,000 $\mathrm{kWh} /$ year per unit of use. When modifying the networks with any of the aforementioned technologies, the consumption income per unit remains below $25,000 \mathrm{kWh} /$ year, except for a single value that reaches $75,000 \mathrm{kWh} /$ year. The analysis of the frequency of the value shows that the middle energy consumption values tend to disappear, taking part of the lower values, which indicates that the systems that are treated tend to have lower energy requirements.

When GHG emissions are compared, the values obtained have ranges that exceed $50 \mathrm{tCO}_{2}$ /year, with a peak value of $250 \mathrm{tCO}_{2}$ /year. Unlike the initial state of the networks, 
when installing an artifact or modifying its operation, the GHG emission remains below $26 \mathrm{tCO}_{2}$ /year, with an exceptional peak value of $77 \mathrm{t} \mathrm{CO}_{2}$ /year.

Figure 9 shows how in the initial operation, the energy cost related to water per consumption unit reaches a peak value of EUR 32,000/year and other around EUR 10,000/year values. In contrast to the results obtained in the modified systems, the exceptional peak value reached EUR 10,000/year, and all the other networks remain below EUR 3000/year.
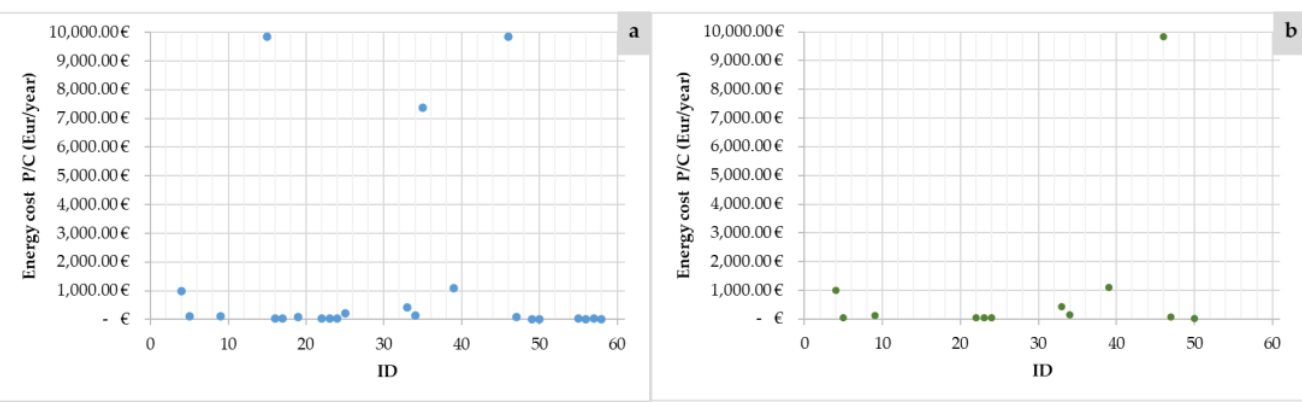

Figure 9. Energy cost related to water usage per capita or per Ha for OS (a) and MS (b).

The modifications to which the exposed networks were subjected in the case studies required a high investment cost for the installation of the element capable of performing energy recovery. On the other hand, the alterations that only had to do with modifying the operating rules dissipated the energy with pressure-reducing valves, so it can be admitted that they lacked energy recovery.

\subsection{Improvements of the Hybrid Systems Applied in Water Systems in the Sustainability}

Improving hydraulic efficiency in a water distribution network is a necessary alternative capable of increasing the energy efficiency of an entire system [94]. Each stage that water is subjected to involves energy expenditure. That is why ways to reduce the amount of energy required by the system are sought. The use of renewable energies (i.e., wind energy, solar energy) has grown in popularity thanks to the fact that they do not emit greenhouse gases and therefore have a lower environmental impact.

There are water distribution systems for irrigation and domestic use that used photovoltaic energy to supply energy to pumping equipment (PVP). It has been shown that a pumping system powered by solar panel energy can reach operating flow rates of up to $3.5 \mathrm{~L} / \mathrm{s}$ and pressures of up to $10 \mathrm{~m}$ w.c. [95]. The PVP is used to irrigate arid climate zones, and it is also considered a parameter to be taken into consideration for the selection of pumping equipment [96].

Another strategy to improve the efficiency of the water system is to control the pressure throughout the network. The elements commonly used to release energy are the valves, but in recent years the administration of pressure regulating the pumping systems and the use of PATs have been booming. The valves are used to reduce the pressure at specific points, which causes the volume of leaked water to decrease, consequently reducing the flow of water injected into the network and the working power of the pumping equipment [97]. In the same way, the programming of the pumping equipment makes it provide the minimum energy required, thus reducing the pressure and power of the station [34]. Like valves, PATs reduce pressure at a specific place in the network, but unlike valves, PATs do not dissipate energy but rather function as micro-hydroelectric plants to recover it [45].

Pressure reducing valves (PRVs) have a simple design and operation, and compared with other control strategies, the investment is considered minimal. Their function only works to lose energy through dissipation, and therefore it is not recoverable $[54,56,57]$. Compared with this, the use of velocity control in pumps systems for regulation purposes is much more convenient [98]. In the case of the programming of the pumping station, it is possible to get the equipment to work at its point with better efficiency, which favors the decrease in energy demand. A disadvantage is that these strategies require the installation 
of valves and electronic equipment [34]. In the case of the pumps used as turbines (PATs), it is possible to achieve energy recovery and at the same time a better control of the pressure in the different points of the network [15]. PATs carry a high value of invention; it is necessary to install valves, and their design, both sizing and operational, tends to be very complex $[15,51,58]$. Additionally, the use of PATs contributes to a reduction in leakages, and therefore this reduction implies an increase in the energy efficiency of the water systems as well as a reduction of the friction losses since the circulating flow is reduced [59,60].

Similarly, water turbines (WT) are the most efficient elements with respect to the creation of energy from water, as referenced in [61-63]. There are also hybrid technologies that emerge after combining the strategies and in this way increase the production or recovery of energy in a pressurized water network. This is called hydroelectric regulation, which works to control the characteristics of the water (both pressure and flow) based on automated devices that always achieve the most optimal operating point [45].

Table 4 shows the modification in the different sustainability indicators considered in water networks when the operation systems were modified, including some renewable hybrid systems. The technologies used to carry out the modified system were pumps used as turbines (PATs), photovoltaic panels (PVP), water turbines (WT), changes in programming or operating mode (COM), installation of pressure-reducing valves (PRV) and hydroelectric regulators (HER).

The energy production or greenhouse gas emission reduction systems in activities related to the use of agricultural or domestic water were analyzed in this research to determine the sustainability of the systems using a comparison of an original (initial) system (OS) with a modified system (MS), of which the parameters of energy consumption, energy production, emission of gases with greenhouse effects and energy cost related to water were determined.

It can be seen how energy consumption to a greater extent is modified when performing any of the techniques where, in COM, the average energy consumption of the case studies varies from $70 \mathrm{GWh}$ /year to $10 \mathrm{GWh}$ /year. It is also worth mentioning that, regarding energy production, the use of PVP causes an increase from 0 to $20 \mathrm{MWh} /$ year.

It should be noted that Table 4 indicates that energy consumption is higher when modifying the system and therefore causes an increase in energy costs related to water. This is a crucial point because it shows that when implementing a modification in a system, the decrease in energy requirements and/or costs related to water use will not necessarily occur.

In relation to the emission of greenhouse gases derived from the use of water, the most effective technique to reduce this indicator is the use of PVP since it presents a decrease greater than $95 \%$ of the initial emission value, which corresponds to a value of almost $20,000 \mathrm{t} \mathrm{CO}_{2} \mathrm{e} /$ year. Similarly, the systems that use wind turbines for electricity generation as an energy source have a reduction greater than $90 \%$, followed by the WT and the COM, having values that are around a $90 \%$ reduction in mass of GHG to the atmosphere.

In the case of the water-energy economic relationship shown in Table 4, the technologies capable of producing higher financial income in the companies in charge of supplying water are firstly, the PVP, which is followed by wind energy production. It is also worth mentioning that the technology capable of reducing the energy cost the most is the installation of WT, thanks to the fact that these managed to reduce the average annual investment value for water-related energy from EUR 3,500,000/year to a value of EUR 50,000/year.

When carrying out a study focused on energy production according to the different technologies mentioned above, the technology with the highest energy production capacity is PVP installation, reaching values of $2000 \mathrm{MWh}$ /year, followed by wind energy with $600 \mathrm{MWh} /$ year. 
Table 4. Original Operation System and Modified Operation System.

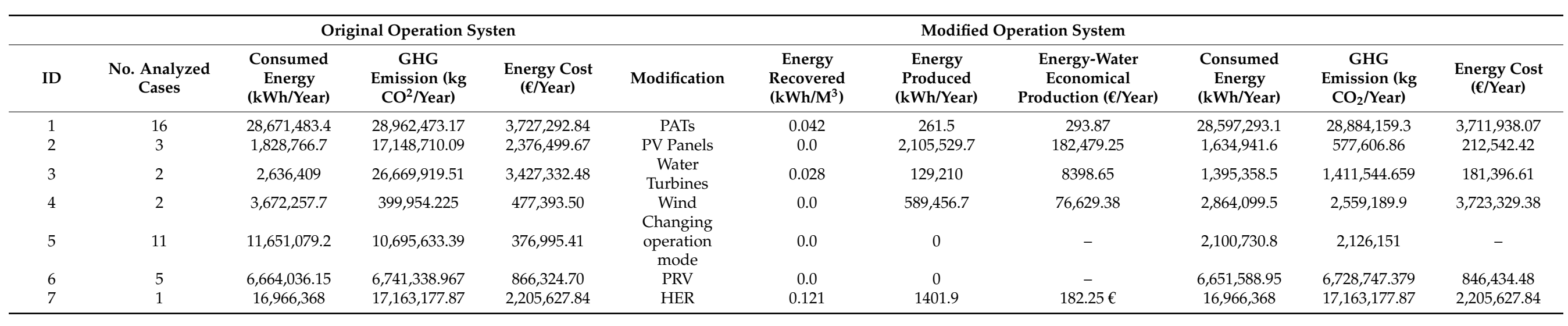


Regarding energy recovery, the values are shown in Table 4 . They indicate that only three techniques of those analyzed are used to recover energy from the network, with the highest recoverable HER being able to reach values obtained from energy per cubic meter of $0.12 \mathrm{kWh} / \mathrm{m}^{3}$ injected into the network, followed by PATs with $0.04 \mathrm{kWh} / \mathrm{m}^{3}$ and lastly the WT, reaching values of $0.03 \mathrm{kWh} / \mathrm{m}^{3}$.

Table 5 shows a summary of the point at which the United Nations sustainable development goals were taken, as a reference for the approach to be given in this research to each of the case studies shown and analyzed. Table 5 shows that the different published methodologies caused improvement in some specific targets but that they did not contribute to global improvements in sustainability. SDG-7 was improved in $72 \%$ of the analyzed case studies (44 of 61). In 20 water systems, this improvement was focused on the use of renewable energies to reduce non-renewable energy, which was consumed in the water systems. The efficiency of the water systems was considered in 12 case studies ( $20 \%$ of the analyzed case studies) and reduction of GHG was estimated in another 12 case studies. SDG-6 was considered in seven cases, focusing on the implementation of water resources management. Finally, SDG-11 was analyzed in 10 water systems, in which urban planning integration of the sustainable measures was the main target.

Table 5. Summary of study cases emphasizing SDGs.

\begin{tabular}{|c|c|c|}
\hline SDG & Target & ID \\
\hline SDG-7. Clean Energy & $\begin{array}{l}\text { Increase substantially the share of } \\
\text { renewable energy in the global } \\
\text { energy mix }\end{array}$ & $\begin{array}{c}1,2,3,4,6,7,8,10,13,18,21,22,23, \\
24,25,26,27,28,29,30,31,36,37, \\
38,51,52,53,60,61\end{array}$ \\
\hline SDG-7. Clean Energy & $\begin{array}{l}\text { Double the global rate of } \\
\text { improvement in energy efficiency }\end{array}$ & $\begin{array}{c}1,3,4,10,26,27,28,29,30,39,46, \\
50\end{array}$ \\
\hline SDG-7. Clean Energy & $\begin{array}{l}\text { Reduce the amount of greenhouse } \\
\text { gas emissions to take action in the } \\
\text { fight against global warming }\end{array}$ & $\begin{array}{c}20,32,33,34,47,48,54,55,56,57, \\
58,59\end{array}$ \\
\hline SDG-6. Water and Sanitation & $\begin{array}{l}\text { Implement integrated water } \\
\text { resources management at all } \\
\text { levels, including through } \\
\text { transboundary }\end{array}$ & $9,11,15,16,17,41,49$ \\
\hline $\begin{array}{l}\text { SDG-11 Sustainable Cities and } \\
\text { Communities }\end{array}$ & $\begin{array}{c}\text { Enhance inclusive and sustainable } \\
\text { urbanization and capacity for } \\
\text { participatory, integrated and } \\
\text { sustainable human settlement } \\
\text { planning and management }\end{array}$ & $5,12,14,19,35,40,42,43,44,45$ \\
\hline
\end{tabular}

\section{Conclusions}

An analysis of different case studies was carried out, showing how strategies and technologies focused on increasing the efficiency of pressurized water distribution networks have been implemented, increasing sustainability indicators. There are different ways to improve the sustainability of water networks. It can be highlighted that several aspects can be followed: the production of "clean" energy, the recovery of energy in the networks or the reduction of energy required.

The analysis of the case studies showed the need to join different optimization functions, which could measure different targets of the different SDGs. An improvement of the efficiency was present in more than $70 \%$ of the case studies, but there are other targets that are important, and they are included on different SDGs (different to SDG-7). Other SDGs, such as economic growth (SDG-8), responsible consumption (SDG-12), no poverty (SDG-1) and zero hunger (SDG-2) must be considered in new approaches to improving the sustainability of water systems globally.

The new challenges in water management and water development planning should be aligned considering the SDGs, and the proposal of sustainable tools should be developed. These should consider the different targets of the SDGs, such as optimization functions, where the constraints weigh the influence of all the variables (measurable and 
non-measurable). The analysis of the different case studies demonstrated that efficiency improvement is not the only main strategy to reach a sustainable development in the urban and farm water systems. The present research considered 61 different case studies, which enabled characterization and estimation of the trends of the different indicators. The work was limited to the published parameters of each case study, and some of them should be estimated as a function of the network type. The increase of new case studies as well as the measurement of other parameters by water managers could enable development of new optimized strategies that define global sustainability linked to SDGs.

Taking these indicators into account, this research sought to show various attempts to achieve more sustainable forms of water distribution in pressurized networks and the they results obtained. In this sense, the use of technologies for the production of clean energy, energy recovery instead of dissipation, reprogramming of pumping stations and hybrid systems were analyzed.

Author Contributions: Conceptualization, P.A.L.-J. and M.P.-S.; methodology, A.V.M.G.; software, writing—original draft preparation, A.V.M.G. and M.P.-S.; writing—review and editing, M.P.-S. and P.A.L.J.; visualization, F.-J.S.-R. and M.P.-S.; supervision, P.A.L.-J. All authors have read and agreed to the published version of the manuscript.

Funding: This research received no external funding.

Institutional Review Board Statement: Not applicable.

Informed Consent Statement: Not applicable.

Data Availability Statement: Not applicable.

Conflicts of Interest: The authors declare no conflict of interest.

\section{References}

1. La Relación Entre el Agua y la Energía I iAgua. Available online: https:/ / www.iagua.es/noticias/h2orizon/relacion-agua-y-ene rgia (accessed on 19 July 2020).

2. Cabrera, E.; Pardo, M.A.; Cobacho, R. Energy Audit of Water Networks. J. Water Resour. Plan. Manag. 2010, 136, 669-677. [CrossRef]

3. Wolff, G. Agua y energía en California. Ing. Agua 2010, 17, 201-211. [CrossRef]

4. Wouters, P.; Rieu-Clarke, A. Sustainability Criteria for Water Resource Systems. Resour. Policy 2001, 27, 139-140. [CrossRef]

5. El Agua en la Agricultura. Available online: https://www.bancomundial.org/es/topic/water-in-agriculture\#1 (accessed on 19 July 2020).

6. Gestión de Recursos Hídricos: Panorama General. Available online: https://www.bancomundial.org/es/topic/waterresources management (accessed on 19 July 2020).

7. OECD Agricultural Policies in OECD Countries 2007. Agricultural Policies in OECD Countries 2005; OECD: Paris, France, 2007.

8. Van Der Kooij, S.; Zwarteveen, M.; Kuper, M. The material of the social: The mutual shaping of institutions by irrigation technology and society in Seguia Khrichfa, Morocco. Int. J. Commons 2015, 9, 129. [CrossRef]

9. Bakker, K.; Cook, C. Water Governance in Canada: Innovation and Fragmentation. Int. J. Water Resour. Dev. 2011, 27, 275-289. [CrossRef]

10. Caniglia, B.; Frank, B.; Kerner, B.; Mix, T.L. Water Policy And Governance Networks: A Pathway To Enhance Resilience Toward Climate Change. Sociol. Forum 2016, 31, 828-845. [CrossRef]

11. Luque, J. Evaluacion de la eficiencia de un proyecto tipico de modernizacion de regadios. Rev. Española Estud. Agrosoc. Pesq. 2011, 2011, 119-145. [CrossRef]

12. UNESCO. The United Nations World Water Development Report 2018: Nature-Based Solutions for Water; UNESCO: Paris, France, 2018.

13. García, I.F.; Díaz, J.A.R.; Poyato, E.C.; Montesinos, P. Optimal Operation of Pressurized Irrigation Networks with Several Supply Sources. Water Resour. Manag. 2013, 27, 2855-2869. [CrossRef]

14. Daccache, A.; Lamaddalena, N.; Fratino, U. On-demand pressurized water distribution system impacts on sprinkler network design and performance. Irrig. Sci. 2010, 28, 331-339. [CrossRef]

15. Romero, L.; Pérez-Sánchez, M.; López-Jiménez, P.A. Improvement of sustainability indicators when traditional water management changes: A case study in Alicante (Spain). AIMS Environ. Sci. 2017, 4, 502-522. [CrossRef]

16. Rucka, J.; Holešovský, J.; Sucháček, T.; Tuhovcak, L. An Experimental Water Consumption Regression Model for Typical Administrative Buildings in the Czech Republic. Water 2018, 10, 424. [CrossRef]

17. Kou, L.; Li, X.; Lin, J.; Kang, J. Simulation of Urban Water Resources in Xiamen Based on a WEAP Model. Water 2018, 10, 732. [CrossRef] 
18. Salam, A. Internet of Things for Water Sustainability. Electrochem. Sens. Carcinog. Beverages 2019, 2020, 113-145. [CrossRef]

19. Mikulčić, H.; Baleta, J.; Klemeš, J.J. Sustainability through combined development of energy, water and environment systems. J. Clean. Prod. 2020, 251, 119727. [CrossRef]

20. Yuan, M.-H.; Chiueh, P.-T.; Lo, S.-L. Measuring urban food-energy-water nexus sustainability: Finding solutions for cities. Sci. Total Environ. 2021, 752, 141954. [CrossRef]

21. Wu, L.; Elshorbagy, A.; Pande, S.; Zhuo, L. Trade-offs and synergies in the water-energy-food nexus: The case of Saskatchewan, Canada. Resour. Conserv. Recycl. 2021, 164, 105192. [CrossRef]

22. Zapata, A.L.; Planeta, E.L.; Vida, L.A.; Agua, E.L.; Ciudad, L.A. URBANO Calidad de Vida Urbana Sectorial. 2002. Available online: http:/ / revistas.ubiobio.cl/index.php/RU/article/view/597 (accessed on 12 March 2021).

23. Munasinghe, M. Water Resource Applications. In Sustainability in the Twenty-First Century; Cambridge University Press: Cambridge, UK, 2019; pp. 402-435. [CrossRef]

24. Food and Agriculture Organization. Sistema Mundial de Información de la FAO Sobre el Agua en la Agricultu-ra. Available online: http:/ / www.fao.org/aquastat/es/overview/methodology/water-use (accessed on 20 July 2020).

25. Adams, A.S.; Pablos, N.P. Factores que afectan la demanda de agua para uso doméstico en México. Región Soc. 2016, 22. [CrossRef]

26. Rascón, L.E.M.; Román, A.J. Alteración del ciclo hidrológico en la parte baja de la cuenca alta del río Lerma por la transferencia de agua a la Ciudad de México. Investig. Geográficas 2001, 1. [CrossRef]

27. Wakeel, M.; Chen, B. Energy Consumption in Urban Water Cycle. Energy Procedia 2016, 104, 123-128. [CrossRef]

28. Shrestha, E.; Ahmad, S.; Johnson, W.; Shrestha, P.; Batista, J.R. Carbon footprint of water conveyance versus desalination as alternatives to expand water supply. Desalination 2011, 280, 33-43. [CrossRef]

29. Wakeel, M.; Chen, B.; Hayat, T.; Alsaedi, A.; Ahmad, B. Energy consumption for water use cycles in different countries: A review. Appl. Energy 2016, 178, 868-885. [CrossRef]

30. Wheater, H.S. Water in a changing world. Biol. Wastewater Treat. 2000, 3, 17-65.

31. Plappally, A.; Lienhard, J.H. Energy requirements for water production, treatment, end use, reclamation, and disposal. Renew. Sustain. Energy Rev. 2012, 16, 4818-4848. [CrossRef]

32. Department of Energy. Energy Demands on Water Resources; Report to Congress on the In-terdependency of Energy and Water; Technical Information Center Oak Ridge Tennessee: Washington, DC, USA, 2006.

33. Carravetta, A.; Fecarotta, O.; Sinagra, M.; Tucciarelli, T. Cost-Benefit Analysis for Hydropower Production in Water Distribution Networks by a Pump as Turbine. J. Water Resour. Plan. Manag. 2014, 140, 04014002. [CrossRef]

34. Luna, T.; Ribau, J.; Figueiredo, D.; Alves, R. Improving energy efficiency in water supply systems with pump scheduling optimization. J. Clean. Prod. 2019, 213, 342-356. [CrossRef]

35. Rosado, L.E.C.; López-Jiménez, P.A.; Sánchez-Romero, F.-J.; Fuertes, P.C.; Pérez-Sánchez, M. Applied Strategy to Characterize the Energy Improvement Using PATs in a Water Supply System. Water 2020, 12, 1818. [CrossRef]

36. Darvini, G.; Soldini, L. Pressure control for WDS management. A case study. Procedia Eng. 2015, 119, 984-993. [CrossRef]

37. Karimov, A.; Molden, D.; Khamzina, T.; Platonov, A.; Ivanov, Y. A water accounting procedure to determine the water savings potential of the Fergana Valley. Agric. Water Manag. 2012, 108, 61-72. [CrossRef]

38. García, I.F.; Novara, D.; Mc Nabola, A. A Model for Selecting the Most Cost-Effective Pressure Control Device for More Sustainable Water Supply Networks. Water 2019, 11, 1297. [CrossRef]

39. Ramos, H.M.; Zilhao, M.; López-Jiménez, P.A.; Pérez-Sánchez, M. Sustainable water-energy nexus in the optimization of the BBC golf-course using renewable energies. Urban Water J. 2019, 16, 215-224. [CrossRef]

40. Pérez-Sánchez, M.; Sánchez-Romero, F.J.; López-Jiménez, P.A. ¿Cuál es la Mejor Consigna para Operar con Bombas Trabajando como Turbinas? EN VI Jornadas de Ingeniería del Agua (JIA 2019); Universidad de Castilla-La Mancha: Toledo, Spain, 2019.

41. Liberatore, S.; Sechi, G.M. Location and Calibration of Valves in Water Distribution Networks Using a Scatter-Search Metaheuristic Approach. Water Resour. Manag. 2008, 23, 1479-1495. [CrossRef]

42. Pérez-Sánchez, M.; Sánchez-Romero, F.J.; Ramos, H.M.; López-Jiménez, P.A. Modeling Irrigation Networks for the Quantification of Potential Energy Recovering: A Case Study. Water 2016, 8, 234. [CrossRef]

43. García, J.P.; Marco, A.C.; Santos, S.N. Use of Centrifugal Pumps Operating as Turbines for Energy Recovery in Water Distribution Networks. Two Case Study. Adv. Mater. Res. 2010, 107, 87-92. [CrossRef]

44. Morillo, J.G.; McNabola, A.; Camacho, E.; Montesinos, P.; Díaz, J.R. Hydro-power energy recovery in pressurized irrigation networks: A case study of an Irrigation District in the South of Spain. Agric. Water Manag. 2018, 204, 17-27. [CrossRef]

45. Pérez-Sánchez, M.; Ferreira, A.R.; López-Jiménez, P.A.; Ramos, H.M. Design strategy to maximize recovery energy towards smart water grids: Case study. Urban Water J. 2018, 15, 329-337. [CrossRef]

46. Fontana, N.; Giugni, M.; Portolano, D. Losses Reduction and Energy Production in Water-Distribution Networks. J. Water Resour. Plan. Manag. 2012, 138, 237-244. [CrossRef]

47. Lydon, T.; Coughlan, P.; McNabola, A. Pressure management and energy recovery in water distribution networks: Development of design and selection methodologies using three pump-as-turbine case studies. Renew. Energy 2017, 114, 1038-1050. [CrossRef]

48. Samora, I.; Franca, M.J.; Schleiss, A.J.; Ramos, H.M. Simulated Annealing in Optimization of Energy Production in a Water Supply Network. Water Resour. Manag. 2016, 30, 1533-1547. [CrossRef]

49. Behandish, M.; Wu, Z. Concurrent Pump Scheduling and Storage Level Optimization Using Meta-models and Evolutionary Algorithms. Procedia Eng. 2014, 70, 103-112. [CrossRef] 
50. Adhau, S.; Moharil, R.; Adhau, P. Mini-hydro power generation on existing irrigation projects: Case study of Indian sites. Renew. Sustain. Energy Rev. 2012, 16, 4785-4795. [CrossRef]

51. Sitzenfrei, R.; Von Leon, J. Long-time simulation of water distribution systems for the design of small hydropower systems. Renew. Energy 2014, 72, 182-187. [CrossRef]

52. Samora, I.; Manso, P.; Franca, M.J.; Schleiss, A.J.; Ramos, H.M. Energy Recovery Using Micro-Hydropower Technology in Water Supply Systems: The Case Study of the City of Fribourg. Water 2016, 8, 344. [CrossRef]

53. Carravetta, A.; Fecarotta, O.; Del Giudice, G.; Ramos, H. Energy Recovery in Water Systems by PATs: A Comparisons among the Different Installation Schemes. Procedia Eng. 2014, 70, 275-284. [CrossRef]

54. Brunone, B.; Meniconi, S.; Ferrante, M.; Carrettini, C.; Chiesa, C.; Capponi, C.; Segalini, D. The Characterization of Milan WDS by Pumping Switching off: Field Test Assesment. Procedia Eng. 2014, 70, 201-208. [CrossRef]

55. Manolakos, D.; Papadakis, G.; Papantonis, D.; Kyritsis, S. A simulation-optimisation programme for designing hybrid energy systems for supplying electricity and fresh water through desalination to remote areas. Energy 2001, 26, 679-704. [CrossRef]

56. Xu, Q.; Chen, Q.; Ma, J.; Blanckaert, K.; Wan, Z. Water Saving and Energy Reduction through Pressure Management in Urban Water Distribution Networks. Water Resour. Manag. 2014, 28, 3715-3726. [CrossRef]

57. Ramos, H.M.; Kenov, K.N.; Vieira, F. Environmentally friendly hybrid solutions to improve the energy and hydraulic efficiency in water supply systems. Energy Sustain. Dev. 2011, 15, 436-442. [CrossRef]

58. Gonçalves, F.; Costa, L.; Ramos, H.M. Best economical hybrid energy solution: Model development and case study of a WDS in Portugal. Energy Policy 2011, 39, 3361-3369. [CrossRef]

59. Tabesh, M.; Hoomehr, S. Consumption management in water distribution systems by optimizing pressure reducing valves' settings using genetic algorithm. Desalination Water Treat. 2009, 2, 96-102. [CrossRef]

60. Pérez-Sánchez, M.; Sánchez-Romero, F.J.; López-Jiménez, P.A.; Ramos, H.M. PATs selection towards sustainability in irrigation networks: Simulated annealing as a water management tool. Renew. Energy 2018, 116, 234-249. [CrossRef]

61. Moreno, M.A.; Carrión, P.A.; Planells, P.; Ortega, J.F.; Tarjuelo, J.M. Measurement and improvement of the energy efficiency at pumping stations. Biosyst. Eng. 2007, 98, 479-486. [CrossRef]

62. Bohórquez, J.; Saldarriaga, J.G.; Vallejo, D. Pumping Pattern Optimization in Order to Reduce WDS Operation Costs. Procedia Eng. 2015, 119, 1069-1077. [CrossRef]

63. Carrillo-Cobo, M.T.; Camacho-Poyato, E.; Montesinos, P.; Díaz, J.A.R. Assessing the potential of solar energy in pressurized irrigation networks. The case of Bembézar MI irrigation district (Spain). Span. J. Agric. Res. 2014, 12, 838-849. [CrossRef]

64. Venkatesh, G.; Chan, A.; Brattebø, H. Understanding the water-energy-carbon nexus in urban water utilities: Comparison of four city case studies and the relevant influencing factors. Energy 2014, 75, 153-166. [CrossRef]

65. Pérez-Urrestarazu, L.; Díaz, J.A.R.; Poyato, E.C.; Luque, R.L. Quality of Service in Irrigation Distribution Networks: Case of Palos de la Frontera Irrigation District (Spain). J. Irrig. Drain. Eng. 2009, 135, 755-762. [CrossRef]

66. Cobo, M.C.; Poyato, E.C.; Montesinos, P.; Díaz, J.R. New model for sustainable management of pressurized irrigation networks. Application to Bembézar MD irrigation district (Spain). Sci. Total Environ. 2014, 473-474, 1-8. [CrossRef]

67. Christodoulou, S.; Agathokleous, A. A study on the effects of intermittent water supply on the vulnerability of urban water distribution networks. Water Supply 2012, 12, 523-530. [CrossRef]

68. Cabrera, E.; Del Teso, R.; Gómez, E.; Estruch-Juan, E.; Soriano, J. Quick energy assessment of irrigation water transport systems. Biosyst. Eng. 2019, 188, 96-105. [CrossRef]

69. Daccache, A.; Lamaddalena, N.; Fratino, U. Assessing Pressure Changes in an On-Demand Water Per-formance-Case Study in Italy. J. Irrrigation Drain Eng. 2010, 136, 261-270. [CrossRef]

70. Al-Smairan, M. Application of photovoltaic array for pumping water as an alternative to diesel engines in Jordan Badia, Tall Hassan station: Case study. Renew. Sustain. Energy Rev. 2012, 16, 4500-4507. [CrossRef]

71. Zhou, S.; McMahon, T.; Walton, A.; Lewis, J. Forecasting daily urban water demand: A case study of Melbourne. J. Hydrol. 2000, 236, 153-164. [CrossRef]

72. Cabrera, E.; Cobacho, R.; Soriano, J. Towards an Energy Labelling of Pressurized Water Networks. Procedia Eng. 2014, 70, $209-217$. [CrossRef]

73. Ramos, J.; Ramos, H.M. Sustainable application of renewable sources in water pumping systems: Optimized energy system configuration. Energy Policy 2009, 37, 633-643. [CrossRef]

74. Pardo, M.Á.; Riquelme, A.J.; Jodar-Abellan, A.; Melgarejo, J. Water and Energy Demand Management in Pressurized Irrigation Networks. Water 2020, 12, 1878. [CrossRef]

75. Stamouli, P.; Dercas, N.; Baltas, E. Performance analysis of on-demand pressurized irrigation networks-Case study in Greece. Water Util. J. 2017, 16, 39-55.

76. Cabrera, E.; Gomez, E.; Soriano, J.; Espert, V. Energy Assessment of Pressurized Water Systems. J. Water Resour. Plan. Manag. 2015, 141, 04014095. [CrossRef]

77. Dandy, G.; Roberts, A.; Hewitson, C.; Chrystie, P. Sustainability Objectives For The Optimization Of Water Distribution Networks. Water Distrib. Syst. Anal. Symp. 2008, 2007. [CrossRef]

78. Corcoran, L.; McNabola, A.; Coughlan, P. Optimization of Water Distribution Networks for Combined Hydropower Energy Recovery and Leakage Reduction. J. Water Resour. Plan. Manag. 2016, 142, 04015045. [CrossRef] 
79. Santhosh, A.; Farid, A.; Youcef-Toumi, K.; Adegbege, A. Simultaneous co-optimization for the economic dispatch of power and water networks. APSCOM 2012, 2012, 1-6. [CrossRef]

80. Martynov, A.; Sushama, L.; Laprise, R. Simulation of temperate freezing lakes by one-dimensional lake models: Perfor-mance assessment for interactive coupling with regional climate models. Boreal Environ. Res. 2010, 15, 143-164. [CrossRef]

81. Hellström, D.; Jeppsson, U.; Kärrman, E. A framework for systems analysis of sustainable urban water management. Environ. Impact Assess. Rev. 2000, 20, 311-321. [CrossRef]

82. Alegre, H.; Baptista, J.M.; Cabrera, E.; Cubillo, F.; Duarte, P.; Hirner, W.; Merkel, W.; Parena, R. Indicadores de Desempeño para Servicios de Abastecimiento de Agua; Editorial Universitat Politècnica de València: Valencia, Spain, 2018.

83. Pardo, M.A.; Manzano, J.; Cabrera, E.; García-Serra, J. Energy audit of irrigation networks. Biosyst. Eng. 2013, 115, 89-101. [CrossRef]

84. Halkijevic, I.; Vukovic, Z.; Vouk, D. Indicators and a Neuro-Fuzzy Based Model for the Evaluation of Water Supply Sustainability. Water Resour. Manag. 2017, 31, 3683-3698. [CrossRef]

85. Anderson, J. Integrating recycled water into urban water supply solutions. Desalination 2006, 187, 1-9. [CrossRef]

86. Agency, I.E.; Iea, C.M. IEA Statistics 2005; 2004; pp. 1-23. Available online: https://www.iea.org/data-and-statistics?country= WORLD\&fuel=Energy\%20supply\&indicator=TPESbySource (accessed on 20 July 2020).

87. Yang, L.; Zeng, S.; Chen, J.; He, M.; Yang, W. Operational energy performance assessment system of municipal wastewater treatment plants. Water Sci. Technol. 2010, 62, 1361-1370. [CrossRef]

88. Kenway, S.J.; Priestley, A.; Cook, S.; Seo, S.; Inman, M.; Gregory, A.; Hall, M. Energy Use in the Provision and Consumption of Urban Water in AUSTRALIA and New Zealand; Water Services Association of Australia (WSAA): Sydney, Australia, 2008.

89. U.S. EPA. Energy Efficiency in Water and Wastewater Facilities; U.S. Environmental Protection Agency: Washington, DC, USA, 2014.

90. Spadaro, J.V.; Langlois, L.; Hamilton, B. Greenhouse Gas Emissions of Electricity Generation Chains: Assessing the Difference. IAEA Bull. 2000, 42, 18-29.

91. Amblard, L. Collective action as a tool for agri-environmental policy implementation. The case of diffuse pollution control in European rural areas. J. Environ. Manag. 2021, 280, 111845. [CrossRef]

92. Lucian, P. Durable rural Development through the 2014-2020 national rural development program. Stud. Bus. Econ. 2018, 13, 147-152. [CrossRef]

93. Mousavi, N.; Kothapalli, G.; Habibi, D.; Lachowicz, S.W.; Moghaddam, V. A real-time energy management strategy for pumped hydro storage systems in farmhouses. J. Energy Storage 2020, 32, 101928. [CrossRef]

94. Pérez-Sánchez, M.; Sánchez-Romero, F.J.; Ramos, H.M.; López-Jiménez, P.A. Energy Recovery in Existing Water Networks: Towards Greater Sustainability. Water 2017, 9, 97. [CrossRef]

95. Gopal, C.; Mohanraj, M.; Chandramohan, P.; Chandrasekar, P. Renewable energy source water pumping systems-A literature review. Renew. Sustain. Energy Rev. 2013, 25, 351-370. [CrossRef]

96. Pande, P.; Singh, A.; Ansari, S.; Vyas, S.; Dave, B. Design development and testing of a solar PV pump based drip system for orchards. Renew. Energy 2003, 28, 385-396. [CrossRef]

97. Conejos, M.P.; Alzamora, F.M.; Alonso, J.C. A Water Distribution System Model to Simulate Critical Scenarios by Considering Both Leakage and Pressure Dependent Demands. Procedia Eng. 2017, 186, 380-387. [CrossRef]

98. Romero-Marrero, L.; Pérez-Sanchez, M.; López-Jiménez, P.A. Estimación de las curvas características de operación de sistemas de impulsión operando como turbinas a partir de su curva motriz trabajando como bomba. Ing. Agua 2018, 22, 15-26. [CrossRef] 